\title{
New instruments for banking regulation and monetary policy after the crisis
}

\author{
Daniel Detzer *
}

\begin{abstract}
This paper analyzes two instruments - asset-based reserve requirements put forward by Thomas Palley and asset-based capital requirements proposed by Charles Goodhart and Avinash Persaud - regarding their merits in reducing excessive asset price inflation. A theoretical framework of asset pricing based on the ideas of Keynes and Minsky is developed, within which the working of the instruments is demonstrated and analyzed. It is shown that in theory both instruments are able to reduce excessive asset price inflation by reducing the amount of credit money and investment flowing from financial institutions into a booming sector. It is concluded that the effect of asset-based reserve requirements is more predictable and that those are therefore more suitable for the task.

JEL classifications: E05, EI2, E52, GI2, GI8

Keywords: Monetary policy, banking regulation, asset prices, bubbles, Minsky, financial instability hypothesis, asset based reserve requirements, capital requirements, macroprudential regulation
\end{abstract}

\section{Introduction}

The recent financial crisis vividly demonstrated the threat posed by asset price bubbles to financial stability. For a long time, the approach by central banks, which should have an intrinsic interest in financial stability, was mainly not to intervene in the development of bubbles and only to clean up after they bust. This is changing slowly, as demonstrated by

* Berlin School of Economics and Law. For providing constructive comments I would like to thank Prof. Trevor Evans, Prof. Eckhard Hein and the two referees of this journal.

Correspondence Address:

Daniel Detzer, Berlin School of Economics and Law, Badensche Straße 52, I0825 Berlin, Germany, e-mail: daniel.detzer@hwr-berlin.de.

Received 3I January 20I2, accepted I8 May 2012

(C) INTERVENTION 9 (2), 2012, 233-254 
Holz (2007). However, the very blunt instrument of the interest rate, available on a euro area wide level, is not suited for targeting bubbles occurring only in certain asset markets or in certain geographical areas. There is a lack of more precise instruments to prevent the build-up of asset-price bubbles. While not introduced in actual economic policy yet, some academics have developed instruments useful to fulfill this task. Particularly promising seem asset-based reserve requirements (ABRR) put forward by Palley and asset-based capital requirements $(\mathrm{ABCR})^{\mathrm{I}}$ proposed by Goodhart and Persaud. This paper will contribute to the theoretical discussion of these instruments by analyzing them regarding their merits in reducing excessive asset price inflation and so diminish negative consequences for financial stability.

The paper is organized as follows: In Section 2 the build-up of instability is demonstrated with the help of a graphical asset price model which builds mainly on Keynes's ideas on convention and Minsky's financial instability hypothesis. Section 3 demonstrates and examines the functioning of the instruments with the help of the developed model. Section 4 gives a final comparison and concludes.

\section{Time series dimension of instability}

The movement from a stable to a fragile state is described in the macro-prudential literature as the time series dimension of risk. It is portrayed by the IMF (2OII) as a cumulative, amplifying process within the financial system in which risk exposure is increased during an upswing. It manifests itself in excessive leverage and maturity mismatches by financial institutions ${ }^{2}$ (FIs), households and firms. This process makes the whole system more vulnerable to exogenous and endogenous shocks and therefore increases the likelihood of financial crisis. Minsky analyzed this process theoretically in his financial instability hypothesis, which will be outlined in the following sections. ${ }^{3}$

\section{I Minsky's financial instability hypothesis and the margins of safety}

Minsky defines different financing regimes: hedge, speculative and Ponzi. ${ }^{4}$ Depending on which regimes are dominant within the economy, it is relatively stable or will tend to

I Goodhart and Persaud did not give their proposed instrument a specific name, but regarding its characteristics, asset-based capital requirement terms it relatively well.

2 The terms financial institutions and banks are used in the following interchangeably to refer to all kinds of financial intermediaries that provide bank-like services.

3 The following section is based upon Minsky (1975, 1982, 2008a and 2008b).

4 The difference between the different units depends on the timing and amount of free incoming cash-flows compared to the payment commitments a unit incurred through debt financing. A hedge unit has sufficient expected cash flows so that it can serve all future payment commitments (interest and principal), when they occur. A speculative unit's expected cash receipts are sufficient to cover the interest rate, but not to pay back the principal. Only in later periods are the cash flows expected to 
financial instability. Because hedge units have low leverage, high equity and no or only very low maturity mismatches, their success is relatively independent of financial markets. For speculative and even more for Ponzi units, maturity mismatch and leverage increase while equity decreases. They are therefore highly vulnerable to changes in financial market conditions and prone to default. Their default in turn can cause deterioration of financial market conditions. Hence, an economy with many speculative and Ponzi units does not only suffer more from shocks generated by the financial system, but also generates more defaults that feed back into the financial system.

More interesting than the regimes themselves is the process that leads from a stable system to a fragile one. This is explained with the erosion of the margins of safety over the cycle. These margins basically reflect the willingness of borrowers and lenders to allow for debt financing. Minsky connects investment and financing decisions to demonstrate their importance in determining the level of economic activity and their role in creating instability.

He distinguishes two sets of prices as fundamentally important for the level of investment. The prices for newly produced investment goods $\left(P_{I}\right)$ and the prices for already existing capital assets $\left(P_{K}\right)$. The former is determined mainly through wages, labor productivity, short-term interest rates plus a mark-up and is regarded as being constant in the short run. $P_{K}$ depends on the expected gross profits $(Q)$ that an asset will earn and on its embodied liquidity $(l)$. This refers to the ease in which it can be transformed into money.

Both prices together determine investment. For investment to take place at all, it is necessary for the market price of assets to be higher than their production costs $\left(P_{k}>P_{i}\right)$. How investment is determined is shown for a representative firm in Figure I. It expects free available gross profits of $Q_{i}$. This is the amount of internal finance it can commit to new investment. Therewith it can finance an amount of $I_{0}=\frac{Q_{i}}{P_{i}}$. If it decides to purchase $I_{1}>I_{0}$, it will need to finance $P_{i}^{*} I_{1}-Q_{i}$ externally. In doing so, it incurs future cash payment commitments $(P C)$. With the influence of the firm on prices being negligible and unlimited access to finance, it would acquire an infinite amount of I, as long as the capitalized difference between the prospective yields and the commitments accruing through the asset and the incurred financing relation is positive $\left(\hat{K}\left(Q_{i}-P C_{i}\right)>0\right)$.

increase so that it can reimburse the lenders in full. Until then it needs to roll over its debt. A Ponzi unit's incoming expected cash flows are not sufficient to cover the interest payments in any period. Only in some final period is a large cash flow expected which allows for repayment. Until then the unit needs to capitalize interest payments on its balance sheet. Hence, it needs to roll-over the principal and find new financing for the accruing interest. 
Figure I: A firm's financing behavior and the margins of safety

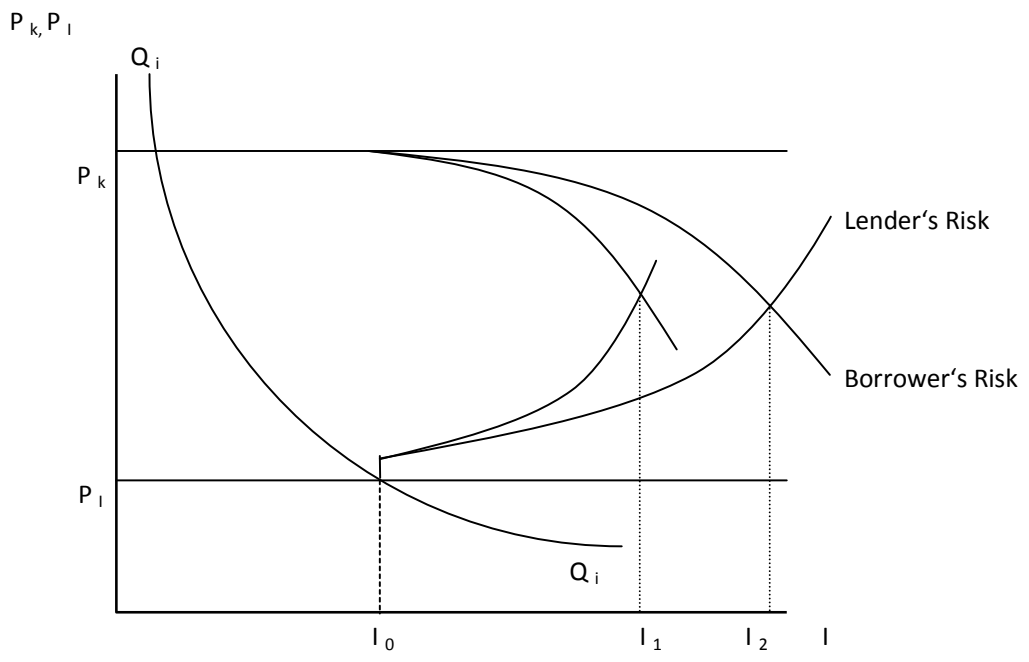

Source: Minsky (1975: 108)

However, profits that an investment yields are uncertain, while payment commitments due to debt are fixed. Hence, with more debt financing the borrower will apply an ever smaller capitalization rate on the $Q s$, which reflects this insecurity. Therefore, with increasing debtfinancing, the demand price for investment falls below $P_{k}$. This allows for expectations to be disappointed to a certain extent without the borrower having difficulties fulfilling his commitments.

While the borrower's risk does not show up in debt contracts explicitly, the lender's risk does. When the debt-equity-ratio increases, it mainly takes the form of an increasing interest rate, but also of higher demand for collateral, shorter maturities and other limitations. The effective supply price that a buyer faces is $P_{I}$ plus the capitalized excess of commitments due to debt financing over the implicit commitments occurring from internal finance. Hence, the lender's risk curve and therefore the effective investment price rises with the amount of debt. It has a discontinuity on its onset because the borrower faces a variety of constraints as soon as he enters a debt contract.

The conjunction of the two curves determines the undertaken investment and the amount of debt financing. It is important to note here that both risks are subjective valuations. While at one point in time an investor might find an investment of $I_{1}$ suitable, at another point in time he might be willing to invest an amount of $I_{2}$. For the lender's risk the situation is similar, while there seems to be a consensus of which debt ratio might be acceptable at any point in time, this consensus can change over the business cycle. The margins of safety change with experience. Right after the experience of a crisis, margins are high and low debt ratios 
are chosen. When expectations about returns turn out to be correct, lenders and borrowers will realize a capital gain and gradually reduce their initial margins of safety, which seemed to be excessive. Experience translates into higher confidence for the borrower about his expected returns (a lower variance) so that his risk curve moves closer to the $P_{k}$ line. At the same time, loans will be repaid in an orderly way so that lenders have an increasing number of customers with a good credit history. Bankers use past credit histories to estimate the risk of potential borrowers. Thus, they will lend more willingly with lower margins of safety. The loss of institutional memory and the tendency to grant riskier loans in good times has been confirmed by empirical studies of the Bank for International Settlements (Berger/Udell 2003). Hence, the lender's risk curve will after a period of tranquility deviate less steeply from the $P_{I}$ schedule than before. Therefore, a higher level of debt financed investment is possible. This in turn has feedback effects. Higher aggregate demand will lead to higher profits that validate the debt structure and add further confidence to borrowers and lenders. Additionally, higher realized profits will change profit expectations and a revaluation of asset prices occurs, which shifts the $P_{K}$ line upwards. In this upward movement the margins of safety are reduced, and eventually expected receipts exceed payment commitments only slightly and throughout the project. Therefore, the overall amount of Ponzi and speculative units increases. And with this, only small deviations can lead to defaults. After this has happened, the process can also work in reverse, expectations are disappointed, borrowers will be more cautious and the view of the lenders over acceptable debt ratios will fall. With this, investment has to fall, profits decline and a downward spiral is amplified.

\subsection{Asset price bubbles}

Minsky's analysis gives insights into the development of financially driven investment cycles that can lead to crises. However, asset-price bubbles in particular have frequently contributed to financial fragility and subsequently to crises. Minsky proposed a framework for the determinants of asset prices. However, he did not explicitly deal with asset price bubbles and their impact on financial stability. To get a better understanding of how asset bubbles develop and how they can disrupt the financial system, the following section will develop a refined framework for asset price determination, which builds on the ideas presented above.

Wray and Tymoigne (2008: 14-16) argue that asset valuations are based on the capitalized value of $q-c+l+a$, where $(q)$ is the expected yield, $(c)$ the costs of carrying, $(l)$ the subjectively valued liquidity and $(a)$ a measure for the expected appreciation or depreciation. A long-term investor would most likely care about the overall yield plus some long-term capital gain. However, speculators care most about short-term capital gains. Here, Keynes's ideas on convention come into play. He argues that there is a conventional view about a 'normal price This price does not rest a priori on fundamentals but it is socially determined by an imitation process, based on his `beauty contest $`$ of anticipating the average opinion about the market price. Bullish and bearish tendencies balance at this price. If average opinion is that the current price is the normal price, there will be only small fluctuations around some average (Wray/Tymoigne 2008: I4-I6). If, however, the convention breaks 
down and a large enough group of individuals assumes that some fundamental change has happened and/or average valuation has changed, significant deviations and movements may occur before a new normal price is established and anchors the actual price. However, there can also be episodes where no new convention is agreed upon and prices fluctuate in large swings or move in one direction without resettling (Davis 1997: 212-213). For better illustration the process is put into Figure 2.

Figure 2: Asset price determination and the margins of safety in a flow model

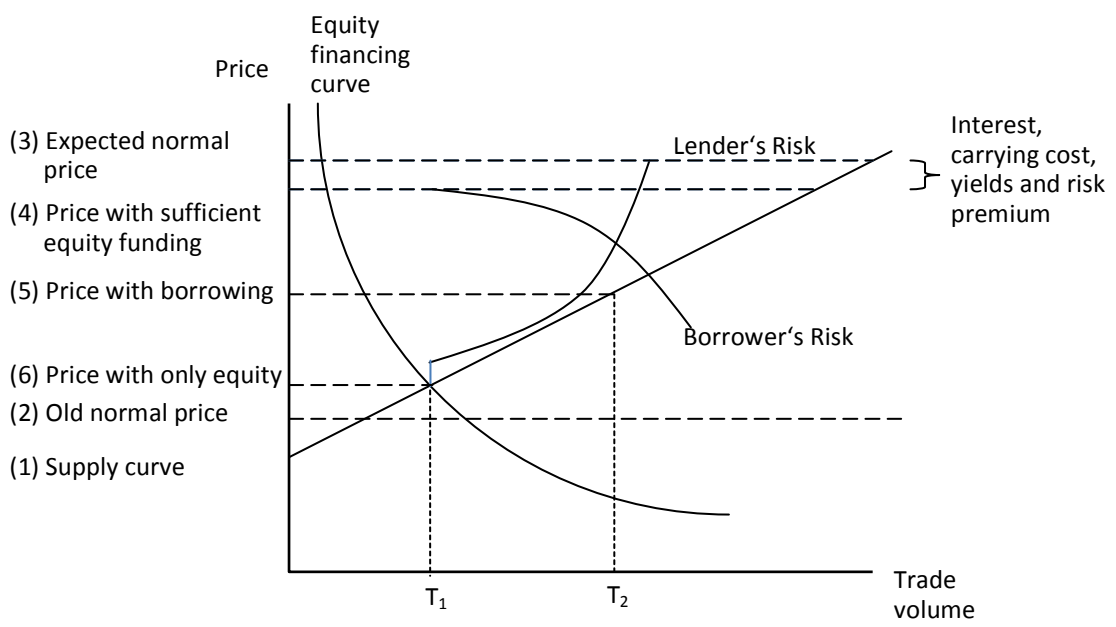

Here, a flow model for a one trading period, which matches current demand and supply, is depicted. Compared to the investment supply curve the asset supply curve (No. I in the graph) is upward sloping, which reflects the flow supply that the current stock holders are willing to sell from the fixed overall stock for a certain price (Bailey 2005: 37). There is an initial normal price (2) around which the market clears and there are no large deviations, as long as the numbers of bulls and bears in the market are roughly equal. However, there can be sudden swings if a sentiment preponderates that the normal price should be different and that therefore a capital gain is possible (Davidson 2002: 194). Kaldor argues that with certain expectations the investors should bid up the current price to the expected price (3) minus carrying cost and interest ${ }^{5}$ plus occurring yields. The current price will deviate additionally from the expected price by a risk premium. This premium will be higher the more uncertainty

$5 \quad$ For Kaldor this included the interest for borrowing plus the opportunity costs of equity. Here it will be taken to just include the equity costs, while the borrowing costs are included in the lender's risk curve. 
about the expected future price exists (Kaldor 1939: 5). This price (4) should be reached if the bullish investors in the market have sufficient funds to finance the acquisition.

However, as in Minsky's model, it is assumed here that the bullish investors only have a certain amount of free funds available (equity finance curve), but they are also able to take loans to finance further asset acquisition. In addition to the risk premium added for equity financing, they add a margin of safety for taking on debt. Therefore, the price for which they are still willing to buy diverges from the price that would be reached if they had sufficient funds. Skepticism about the investors' expectations from the side of the lenders will limit access to finance and make it more expensive as more debt financing is needed (lender's risk curve). Expectations, the availability of funding to translate those expectations into action, and the willingness to use debt will now determine a new current price. Prices could settle here and a new market consensus could be established. However, Kaldor points out that expected prices depend on the past price movements (Kaldor 1939: 7). If the initial price movement changes expectations and the expected price is corrected upwards, capital gains are possible again. Investors that took action initially will be willing to take on more debt and buy at a higher price. Additionally, other investors may revise their opinion too and follow the trend (Davis 1997: 216-217). They may add further demand either through available funds at hand or their free borrowing power. Prices rise further and confidence in further appreciation strengthens. People are willing to buy more on margin and reduce their safety cushions. Fulfilled expectations, orderly repayments and market based risk models convince lenders that risk is low and that they can reduce margins of safety and grant more loans. Additionally, the borrowing capacity of a unit depends on its collateralized net worth. The rising prices increase the net worth of all current asset holders and this increases their access to funds for further speculation (Goodhart/Hofmann 2006: 91-92). In the upward movement, the convention can simply become that the conventional basis for valuation keeps on changing upwards and so additional equity and borrowed money may be used to drive a speculative boom, justifying expectations and fueling euphoria (Wray/Tymoigne 2008: I6).

In such a credit-driven boom, Minsky argues that the need for financing is accommodated by increasingly fragile balance sheets. Households and firms run down cash balances and increase gross-debt-to-equity ratios. Banks that accommodate the increased borrowing requests restructure their balance sheets by selling out liquid assets to provide loans. To hand out more loans, they extend their balance sheets. Growth on the asset side needs to be accommodated by funds on the liability side. Those are arranged by providing close money substitutes to holders of idle cash balances. Since those generally want to hold cash, only short-term borrowing is possible and hence the liability side of bank balance sheets depends on more short-term liabilities. ${ }^{6}$ In the whole process of a boom, balance sheets of all participants become more fragile. There is more and shorter-term debt. More debt creates more fixed payment commitments. Eventually, those commitments are all layered on the profits and wages earned by firms and households (Minsky 1975: 123).

6 In the recent crisis, marginal funding was obtained via wholesale market short term loans (Adrian/ Shin 2008b: 13). 
Hence, in a boom with the declining margins of safety, the system becomes gradually more fragile. More units incur debt relations that are Ponzi- or speculative-like, because the validation of their debt depends on their ability to sell the assets for higher prices. Banks depend on rolling over an increasing amount of short-term debt every period. They are speculative in nature, but they became more fragile in the process. Now, small departures from expectations will force many units to change plans in order to meet payment commitments. This can mean delayed payments, distress borrowing, or even sale of the asset before profits can be realized (Kregel 2008).

However, as long as the boom continues, the debt structure is validated and the system appears artificially robust. Eventually though, with the price of the asset at a high level, more investors may become bearish and start selling. The boom, however, continues as long as banks recycle the resulting cash balances as loans to still bullish investors. If eventually bears gain ground and access to finance for bulls is diminishing, price increases will slow down and eventually come to a halt (Erturk 2006: 463). Units that want to realize their book profits at the peak are not able to find buyers and prices start falling. Investors' expectations get disappointed and they may need to liquidate their position to service their debt. This puts pressure on the market so prices fall further, and now a downward trend is triggered due to the need to liquidate assets, which in turn is caused by the incurred fragile debt structure. Lower asset values diminish the value of available collateral so that banks are less willing to lend. Defaults and higher volatility will increase perceived risk, and margins of safety increase (Minsky 1975: I17-130). Due to the falling asset prices, people that bought on credit may not be able to repay the banks which in turn suffer credit losses, and if they were invested in the assets themselves, banks will be affected by trading losses, too. With this, the credit driven boom can lead to a full-fledged financial crisis.

Then again, not every bubble necessarily destabilizes the financial system. For financial vulnerability to occur, it is decisive whether and at what value inflated assets enter bank balance sheets (Minsky 1982: I44). The upward trend does not need to be fueled by credit. It can also be fueled by more and more investors shifting wealth into the appreciating asset. Barwell and Burrows (20II: 9) examined balance sheets in the UK for the tech bubble and conclude that bank credit was only a minor factor in fueling the boom. Therefore, the stock market crash did not destabilize the financial system to a large extent. Alternatively, an asset price boom can be fueled by credit expansion as described above. This has happened mainly during the recent housing price boom and led to much larger disruptions in the financial sector. Hence, it seems that a credit fueled bubble is much more dangerous than one where the financial sector plays only a peripheral role. Therefore, tools that intend to ensure stability in the financial sector should particularly be concerned with credit-driven bubbles. 


\section{Tools for macro-prudential regulation and policy}

There is no commonly agreed definition of macro-prudential policy. The most encompassing one sees it as policies that aim at maintaining financial stability (IMF 20II). For the purpose of this paper this broad definition will be used. From the previous analysis it can be derived that boom phases, real economic as well as asset price booms, can lead to debt relations and balance sheet structures that make the financial system vulnerable to shocks. Keeping the financial stability point of view of macro-prudential policy in mind, a bubble only seems dangerous if the financial system was involved, either by giving loans for or against inflated assets, or buying them themselves. Hence, one criterion to evaluate these instruments is their ability to dampen unsustainable booms and reduce the exposure of the financial system. In the following sections, the instruments will be introduced and examined with a focus on this criterion.

\section{I Asset-based reserve requirements}

With the aim of reducing systemic risk and pro-cyclicality, Palley proposes a system that would require FIs to hold a certain amount of liquidity in the form of central bank reserves. The exact amount of these asset-based reserve requirements (ABRRs) is determined by the FI's asset composition, whereby booming and particularly risky and undesirable assets would have higher requirements (Palley 2000).

\section{I.I Effect on loan rates and demand}

The basic logic of ABRRs is that the required reserve holdings reduce the profitability of affected loans and assets. An implicit assumption that is made is that necessary reserves are supplied to the financial system by the central bank (CB) so that FIs can always fulfill their requirement and the costs are indeed only the direct costs of the reserves and not the costs of foregone interest. ${ }^{7}$ Higher costs will increase FIs' lending rates and thus cause decreasing demand from creditworthy borrowers. This can be illustrated formally within a model of a generic FI.

The profit maximization of the FI is given by:

$$
\begin{array}{r}
\max _{L, H, D, T, F}=i_{L} L+i_{H} H-\left[a_{L}+p_{L}\right] L-\left[a_{H}+p_{H}\right] H-\left[a_{D}+p_{D}\right] D \\
-\left[a_{T}+p_{T}\right] T-\left[a_{F}+p_{F}\right] F ;
\end{array}
$$

$7 \quad$ The CB supplies reserves against eligible collateral only. In a case where the banks run out of eligible collateral the costs of holding reserves would increase to the opportunity costs of alternative investments or the bank lending into a booming sector could even be quantitatively constraint. However, the collateral pool pledged by the $\mathrm{CB}$ exceeded the outstanding loans on average by about Ioo per cent (ECB 20I0: 97). So a systemic shortage seems unlikely and in normal times with a working interbank market also single banks should not have problems accessing the necessary reserves. 
subject to the balance sheet constraint:

$$
\left[1+k_{L}\right] L+\left[1+k_{H}\right] H=D+T+F,
$$

where $L=$ all other loans,

$H=$ housing loans,

$D=$ short-term deposits,

$T=$ long-term deposits,

$F=$ money market borrowing $(F>0)$ or lending $(F<0)$,

$i_{j}=$ interest rate $(j=L, H, D, T, F)$,

$a_{j}=$ constant marginal cost per dollar of administering loans and liabilities,

$\mathrm{p}_{j}=$ probability per dollar of default on loans,

$k_{j}=$ reserve requirement ratio $(j=L, H)$.

From this, one can derive the following four interest rate equations in terms of the money market rate:

$$
\begin{aligned}
& i_{L}=\left[i_{F}+a_{F}\right]\left[1+k_{L}\right]+a_{L}+p_{L}, \\
& i_{H}=\left[i_{F}+a_{F}\right]\left[1+k_{H}\right]+a_{H}+p_{H}, \\
& i_{D}=i_{F}+a_{F}-a_{D}, \\
& i_{T}=i_{F}+a_{F}-a_{T} .
\end{aligned}
$$

Under the endogenous money view, the money market rate is set by the monetary authorities and is therefore an exogenous variable. Each bank can borrow or lend at the interbank rate, so that this rate sets the benchmark for other rates. For deposit rates, this stems from banks' attempt to equalize marginal costs on all different sources of funding. Hence, deposit rates must equal the total costs of borrowing on the money market minus their respective administrative costs.

Without a reserve requirement on assets $\left(k_{j}=0\right)$, the prices for loans would equal their refinancing costs, an administrative charge and a risk compensation, which is given by the default probability (Palley 2004).

The CB has only very general influence on loan rates. By changing $i_{F}$, a CB can shift the level of interest rates for all loan types up or down, but cannot target one single rate or the spread between rates.

By contrast, ABRRs are a very targeted instrument for CBs. It can oblige FIs to hold reserves against specific types of loans. If the $\mathrm{CB}$ intends to reduce housing loans, the $\mathrm{CB}$ may increase the reserve requirement on housing loans instead of raising short-term interest rates and therewith affect other loans as well. For one euro loaned, a FI must raise additional $k_{H}$ euros and put them as reserves with the CB. This means the refinancing costs increase by $k_{H}{ }^{*}\left[i_{F}+a_{F}\right]$. For example, the average interest rate for loans for house purchases in the euro area was 3.84 per cent in March 20II (ECB 20IIa). The interbank lending rate was 
roughly i per cent (ECB 20IIb). If the $\mathrm{CB}$ would have imposed a reserve requirement of Ioo per cent on housing loans, this would mean that refinancing costs would have increased by I per cent. ${ }^{8}$ The total loan rate should have increased to 4.84 per cent. ${ }^{9}$

How this affects the effective amount of loans is illustrated graphically in Figure 3.

\section{Figure 3: The effect of ABRRs on loan demand}

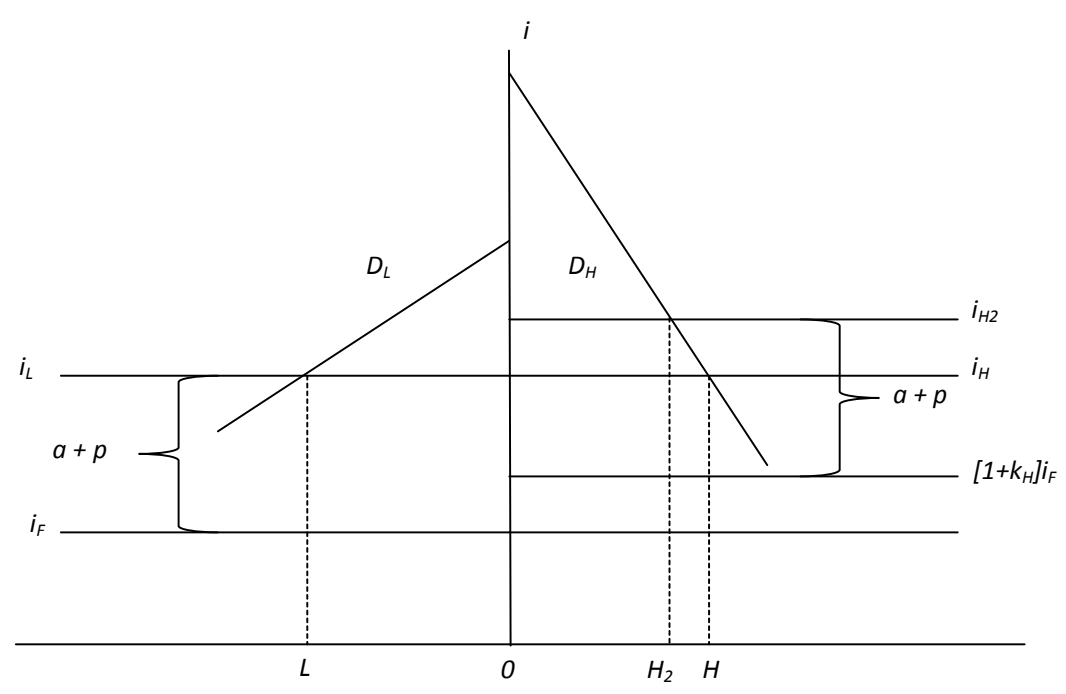

Source: Own illustration, based on Palley (2007: 577)

Assuming that housing loans posses the same characteristics regarding risk and administrational cost as other loans, a bank would charge the same interest rate $\left(i_{L}, i_{H}\right)$ based on the money market rate $\left(i_{F}\right)$. The downward-sloping credit demand curves $\left(D_{L}, D_{H}\right)$ then determine the respective effective quantity for each type of loan $(L, H)$. Without the reserve requirement, the slowing of a potential housing bubble could be achieved by increasing $i_{F}$. This, however, would also increase the interest rates for all other types of loans $\left(i_{L}\right)$ (Palley 2007: 576). If the demand for housing loans is inelastic, as illustrated by the steep curve, the interest rate increase needs to be large to have an effect. This is particularly true for bubbles where

8 Currently, the ECB remunerates reserves with a rate equal to its rate for main refinancing operations. This does annul the intended effect and would have to be abolished to make ABRRs work. 9 This is different from what Holz (2007) or Palley (2007) suggest. They assume that the reserve would increase the loan rates by a multiple of the reserve requirement. If one acknowledged that there are no credit risks and negligible administrative costs for holding central bank reserves, only the interest costs for holding the additional reserves should influence the costs of the loan. 
historical experience suggests that they are not very sensitive to short term interest rates (Dudley 20IO). That would be detrimental to other activities, so that the costs of dampening a bubble can be high. Differently, if the CB can use ABRRs, it can target the desired sector very precisely by raising the refinancing costs from $i_{F}$ to $\left[1+k_{H}\right] i_{F}$ which raises the price customers have to pay to $i_{H 2}$. Confronted with the higher price, customers will reduce borrowing to $H_{2}$. The exact demand effect depends on the interest elasticity in the targeted market (Palley 2007: 576). ${ }^{\circ}$

\section{I.2 Effect on FIs proprietary trading}

In his proposal, Palley (2000: I2) assumes that all kinds of banks as well as other FIs, like mutual, pension or hedge funds, are subject to ABRRs. In order to make the system work, he makes it a precondition that the eligibility rules for the interbank market are changed in a way such that all affected institutions have access. While for ordinary commercial banks the effect of ABRRs works primary through rates of loans made by them, other FIs invest directly in assets. However, with all FIs having access to reserves at the going rate, the effect should not be much different. If monetary authorities want to dampen a stock price boom, they will raise ABRRs on loans for stock purchases and on direct stock investment by FIs. The expected return of the investment in stocks will simply be reduced by the costs of holding the reserves and consequently the attractiveness of an equity investment decreases compared to other investments and will be discouraged (Palley 2003: I4). This can be seen by a simple return on equity calculation. It can again be assumed that the expected monetary return of an asset is comprised of $q-c+a^{\text {II }}$, where most of the carrying costs $(c)$ are the cost of debt financing the acquisition (Minsky 1972: 84). So it can be replaced by the amount of debt financing times the refinancing rate $(1-E q u i t y) i_{F}$. For a given leverage and financing structure the return on equity can be calculated as follows:

$$
R O E_{\text {exp. }}=\frac{\text { Net Income }_{\text {exp. }}}{\text { Equity }}=\frac{q-c+a}{\text { Equity }}=\frac{q-\left[1-{\text { Equity }] i_{F}+a}_{\text {Equity }}\right.}{\text { Eq }} \text {. }
$$

A reserve requirement would now influence the $R O E$ as follows:

$$
R O E_{\exp .}=\frac{q-[1-\text { Equity }+k] i_{F}+a}{\text { Equity }} .
$$

Io Additionally, considering the argument of credit rationing, brought forward by Stiglitz/Weiss (198I), it could be that banks decide to restrict lending when interest rates are pushed up. Consequently, not only demand determines the effective amount of credit. However this line of argument shall not be considered further within this paper.

II Liquidity is not considered here, because return on equity is a monetary measure. However, one could add it to extend the analysis. During a boom the liquidity of an asset increases for a single investor so that he is willing to accept a lower pecuniary return. This allows for higher asset prices and accentuates the boom. For the extension of the analysis one could take a broader definition of return and add liquidity as a variable. 
In consequence, the carrying costs of the stock are increased by the costs of the reserves. While for loans banks are able to increase the interest rate when costs increase and so can hold their margins constant, the expected return on tradable assets is determined in the market and can not be influenced by a single FI. Hence, with the expected return fixed, the increased costs will reduce the return on equity and therefore FIs' incentive to hold assets that are subject to ABRRs.

\section{I.3 ABRRs as an instrument to target bubbles}

After having seen how ABRRs can influence the tendency to invest in specific sectors, in this section the framework developed in section 2 will be used to illustrate how ABRRs will help to reduce asset price bubbles. In Figure 4 this is illustrated graphically.

Figure 4: Asset prices and ABRRs

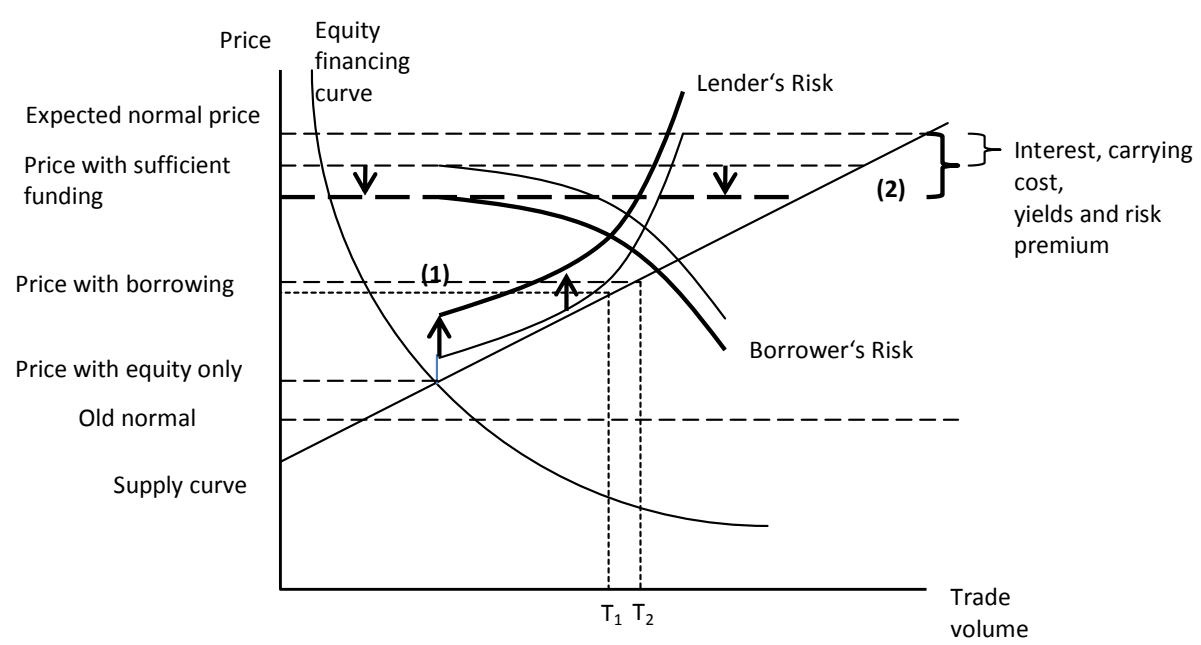

As mentioned above, in an asset price boom, margins of safety are reduced excessively by borrowers and lenders. If the monetary authority were to increase reserve requirements in step, banks would not be able to relax interest rate conditions or would even need to increase them to still make profitable loans. Under stricter credit conditions, fewer borrowers would find it attractive to debt finance their speculation. This can be expressed by an upward shift of the lender's risk curve so that it intersects earlier with the borrower's risk curve. Effective demand for the asset will decline and price increases are reduced (I).

At the same time, FIs that are affected by ABRRs and want to invest in the asset will realize that carrying costs are increased by the interest rate that accrues on reserves during the holding period. Their expected price will stay at the same level, but their possible profits over the gestation period will be lower, so that the price for which they would still be willing 
to buy shifts downwards (2). Further, since Palley's (20I0) reserve requirements will increase in step with the market price of the asset, carrying costs will increase automatically with the market price. When they become large and costly, FIs will be inclined to sell out their asset holdings. That will end a boom earlier than it would otherwise. This could be indicated by a flatter supply curve, since for any price increase more FIs are willing to sell.

To sum up, ABRRs basically have two effects. The boom is dampened because less own investment from the FIs and less credit is directed into the market. Additionally, the ratio of equity to credit invested in the market should increase because credit financed investment becomes relatively less profitable for investors. This, in turn, will reduce the amount of Ponzi and speculative units and a smaller number of assets with less inflated prices enter FIs' balance sheets as collateral so that the effect on the financial sector is reduced in the case of a bust. Whether debt financed investment becomes less profitable for FIs compared to equity finance is questionable and depends on the design of the ABRRs. Holz (2007: 339) notes that if all FIs are subject to reserve requirements, they could be affected twice by the measure. If, for example, a hedge fund invests in the asset, it will have to hold reserves thus lowering the return on the asset. If it additionally finances the acquisition by credit it will be affected by a higher loan rate because the bank would have to hold reserves against the loan. If desired this could be avoided by not having reserve requirements on loans between FIs subject to ABRRs. Additionally, the effect only occurs if the relevant FI acquires funding specifically for the acquisition of the asset. If the funding is organized instead, for example, through repos in the market and is not earmarked to a specific activity, the higher loan rate would not apply even if the money is used for buying an asset that would require reserves.

The effect of ABRRs also depends on their exact implementation. ABRRs could apply to all assets and loans immediately or just to newly accumulated assets. In the first case, the demand for reserves would go up strongly immediately and if the CB meets this by reserve injection to keep the money market rates stable, the effect would be similar to a general interest rate increase, but solely for the targeted asset class. As when the interest rate changes, profitability of long-term loans that are financed short-term would be reduced. However, that is the risk FIs take into account when they pursue maturity transformation. Differently, ABRRs would also hit very prudent organizations that refinanced their longterm loans through long-term liabilities. There would be a possible upside to this effect, though: If banks realize that a bubble is building up and know that the CB may act against it, banks preemptively need to charge higher interest rates and so will dampen an emerging bubble even before the CB acted. Additionally, FIs' own asset holdings would immediately be less profitable, and so they may be inclined to reduce their holdings, increasing flow supply and dampen the boom. In the second case, the effect would be less disruptive. The introduction of ABRRs would only increase the reserve demand gradually and would not shock the profitability of existing loans. It would also not decrease the return on FIs' existing asset holdings but only discourage further investment. Therefore, the second option is less disruptive but is also less effective in pricking a bubble. 


\section{I.4 A note on ABRRs and repos}

The repo market has become an important source of refinancing for many FIs. They are the primary source of funding especially for market-based banking institutions (Brunnermeier et al. 2009: 20). US broker-dealers financed about half of their balance sheets with the help of this short-term market, but they also play a key role for European FIs (Höhrdal/King 2008). On the margin, it seems that many FIs facilitate their balance sheet expansions with the help of the repo market. For many categories of structured debt, haircuts were essentially zero before the crisis. That means that some FIs could finance the acquisition of assets to IOO per cent in the repo market (Gorton 2009: 33). Abstracting from other constraints, they could theoretically leverage their balance sheets indefinitely. Putting a reserve requirement on an asset would now mean that FIs would have to borrow more in the repo market to hold it. For example, a Ioo per cent reserve requirement would work like a 50 per cent haircut because to buy an asset worth Ioo, the FI would have to provide collateral worth 200 . The expansion of balance sheets with the help of the repo market would thus be restricted much earlier. During a crisis, when haircuts increase, the reduced reserve requirements would counteract this effect so that the participants would still get sufficient funds to hold their current asset portfolio with the available collateral.

\subsection{Asset-based capital requirements}

The second instrument under review was proposed by Goodhart and Persaud in a series of articles. ${ }^{\mathrm{I}}$ In contrast to Palley, they advocate using the more traditional regulatory instrument of capital requirements. Those should be calculated on an asset basis and increase when prices in a sector inflate excessively (Goodhart 2009: 95-I00). ${ }^{13}$

\subsection{Effect on loan rates and demand}

The model introduced in section 3.I.I can be modified to show the effect of ABCRs on different types of loans. Introducing a capital charge and dropping the reserve requirements for the moment changes the interest rate structure as in the following way:

$$
\begin{aligned}
& i_{L}=\left[1-C_{L}\right]\left[i_{F}+a_{F}\right]+C_{L}\left[i_{E}+a_{E}\right]+a_{L}+p_{L}, \\
& i_{H}=\left[1-C_{H}\right]\left[i_{F}+a_{F}\right]+C_{H}\left[i_{E}+a_{E}\right]+a_{H}+p_{H},
\end{aligned}
$$

where $E$ = equity,

$$
C_{j}=\text { capital adequacy ratio }(j=L, H) .
$$

I3 The original proposal is much more sophisticated and the increase in the capital requirements depends on the asset price increases, as well as credit growth of each individual bank. However, to be able to compare it with ABRRs the idea has been trimmed down to this basic version. 
As with ABRRs, the authorities are provided with an instrument enabling them to target different asset classes very precisely and so raise interest rates on loans or reduce returns on asset holdings. Their function depends on the assumption that $\left[i_{E}+a_{E}\right]>\left[i_{F}+a_{F}\right]$ holds. However, at least in theory in a frictionless economy without tax distortions and government guarantees, it is claimed that the capital structure will not affect average capital costs (Modigliani/Miller I958). Still, in the real world, those frictions do exist and therefore the above statement should apply (Admati et al. 2010).

Therefore, if the authorities decide to increase the capital requirements for a certain type of loan, this should increase costs for the bank and therefore the interest rate by the difference between the cost of equity and debt financing times the required amount of equity $\left(C\left[\left(i_{E}+a_{E}\right)-\left(i_{F}+a_{F}\right)\right]\right)$. However, quantifying the effect is much harder than with the reserve requirements, because the distortions that make equity cheaper vary from country to country and can also change due to changed legislation or changes in the confidence in government guarantees. Some empirical attempts to find a significant effect from higher equity requirements on loan rates have failed so that there seems to be either no or just a very small effect (Hanson et al. 20II: I8-20). For the moment, however, the widely accepted assumption is followed that equity is more expensive than debt. Therefore, an increased capital requirement should reduce lending to a particular sector the same way an ABRR would. The increased price will reduce demand. The difference is, however, that the increase of the funding costs does not result from increased funding needs but from a changed composition of the funding sources.

However, there is not only a price effect from equity requirements. Equity requirements can be much harder to meet than reserve requirements. While the $\mathrm{CB}$ can provide necessary reserves to the financial system and normally the interbank market should take care of distributing those to the FIs faced by loan demands, it is different for equity. First of all, additional equity can only be raised by retained earnings or issuing additional stock. Depending on the phase of the cycle, it can be very difficult or costly to raise equity. Furthermore, even if the banking system as a whole has sufficient equity, there is no mechanism like the interbank market through which equity can be redistributed to FIs facing demand (Van den Heuvel 2002: 260). So, if banks cannot or do not want to increase their equity, the price effect of a high equity requirement on certain assets may become very substantial since banks have to weight opportunity costs for alternative investments against loans for investment in the asset with the high ABCR in this setting. Hence, it is possible that some loan demand may not be fulfilled despite the fact that borrowers are willing to pay a very high price. These diverse effects on lending policies are confirmed by a range of empirical studies that looked at the effect of the Basel requirements. There are studies where undercapitalized banks decided to raise more equity, but sometimes they shifted from classes with higher requirements to classes with lower requirements or did cut back on lending (Basel Committee on Banking Supervision 1999: 15-19). It was also found that the Basel requirements affect Euro area banks differently than US banks (Karagiannis et al. 20II: 177). Hence, depending on the endowment of the banks with equity, their profit situation, the market conditions for equity, etc., the effect of raising ABCRs may be a price 
effect of varying degree, but could also become a quantitative effect. Therefore, the effects of ABCRs are much harder to predict ex ante.

\subsubsection{Effect on FI' proprietary trading}

How would increased equity requirements change investment decisions by FIs? This question can be answered by looking at equation (6):

$$
R O E_{\text {exp. }}=\frac{\text { Net Income }_{\text {exp. }}}{\text { Equity }}=\frac{q-\left[1-{\text { Equity }] i_{F}+a}_{\text {Equity }}\right.}{\text { Eq }}
$$

An increase in the required equity will increase the numerator slightly by the decrease in the explicit interest costs, but will increase the denominator and therefore reduce the ROE, so that the affected FIs are inclined to invest less in an affected asset. In contrast to Palley, Goodhart (2009: 106-I07) proposes that ABCRs are only put on systemically important FIs which are most likely big banks or some big hedge funds. However, even if it would encompass all FIs, the effect would vary strongly between different institutions. For example, some continental European banks before the crisis had balance sheet leverage multiples of 30. That means on average they had about 3.3 per cent equity for every euro invested (Bank for International Settlements 2009: 7). A relatively high equity requirement of say 20 per cent could surely decrease the ROE for those banks and limit their investment in the concerned asset classes. However, for other FIs the regulation would simply not bite. For example, hedge funds have average leverage multiples of 3-4 (Bank for International Settlements 2009: 8). So for those institutions, a minimum equity requirement that would bite very hard for banks may not have an effect on their investment strategy or their ROE, given their initially higher equity cushion. Therefore, increasing equity requirements for a certain asset class would force undercapitalized institutions to raise additional capital or to reduce investment into this asset class. Since not all FIs would be affected, the measure would be less effective in dampening an asset price bubble.

\subsubsection{ABCRs as an instrument to target bubbles}

As with the ABRRs, the following part examines the effect of ABCRs on asset price bubbles. If FIs can increase their equity easily, the effect of ABCRs will be largely through the price of loans. This can be seen in Figure 5. The lender's risk curve will shift upwards and intersect earlier with the borrower's risk curve, so that the effective demand for the asset will decline and price increases are reduced (I). However, if equity is not freely available, FIs may stop extending loans, limiting speculators' access to borrowed money regardless of what price they are willing to pay and so the lender's risk curve may become vertical at some point (3). This could limit a boom very effectively. However, the logic of countercyclical capital requirements is based on the assumption that raising additional equity during a boom is relatively easy, since profits are high and uncertainty about the financial health of FIs is low (Kowalik 20II: 69). Hence, the first case seems more plausible. 
Additionally, the incentive for FIs to buy the assets themselves is reduced since the leverage that they could use is limited and consequently the profitability of such investment is negatively affected as with the ABRRs (2). However, this time, the effect is due to the higher implicit costs of equity.

Figure 5: Asset prices and ABCRs

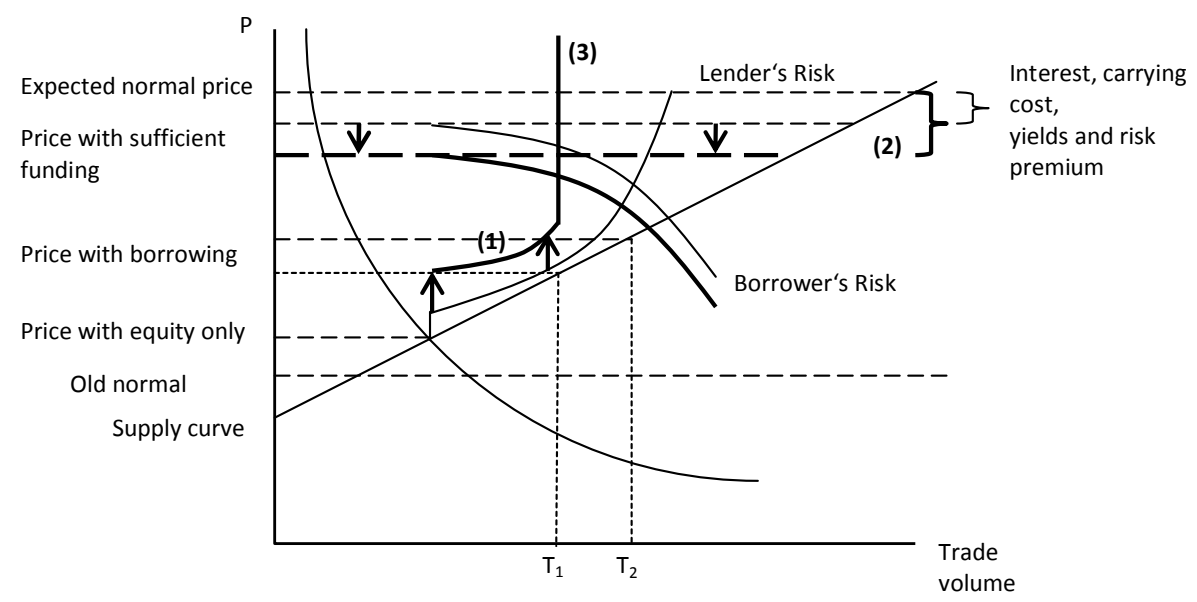

This effect should also be seen in relation to the pro-cyclical effect of FIs' leverage targeting strategies, as for example discussed in Adrian and Shin (2008a). Increasing asset prices increase FIs' equity. Leverage decreases and FIs buy additional assets on credit to hold leverage constant. This in turn leads to higher asset prices and additional equity gains, etc. If the ABCRs are increased in step with growing asset prices, this mechanism could be reduced, disrupted or even overcompensated. The assets would still generate high book profits on FIs' balance sheets. However, the increasing ABCRs would impede expansion of activity on the basis of this new equity. At the same time with a constant growth in the asset class the ROE is falling, so that for the FIs other projects with lower equity requirements become worthwhile, resulting in incentives to sell the ABCR-affected assets and in turn dampening the boom.

There could be another effect. With higher capital requirements in a boom, the bank owners have an increasing amount of 'skin in the gamer. Book profits of risky investments are not available for payout as long as they are not realized through selling the asset. This means that shareholders will lose more if the bank runs into trouble. This may reduce the moral hazard effects generated by limited liability, deposit insurance and bailout expectations (Demirguc-Kunt et al. 20Io). Therefore, the owners of the bank may be more critical of excessive risk taking which may counter the reduction of the margins of safety observed during upswings.

Hence, increasing ABCRs for sectors that are experiencing an asset price bubble will operate in manifold ways. Loans for investors become more expensive, or, in some extreme 
cases, are not available at all. Returns of FIs' own investments are dampened. Additionally, an upward-spiral due to leverage-targeting institutions can be broken or at least be reduced. As mentioned earlier, however, for some important actors the limitation may not be binding since they have high equity ratios anyways.

As with ABBRs, it is an important question whether the equity requirements are imposed on all assets immediately or only on newly acquired ones. Suddenly introduced higher requirements on all assets may push badly capitalized banks below the regulatory requirement. Those FIs would have two options. They could reduce exposure to the booming asset class by selling it, which would be very helpful to disrupt a boom. However, for not marketable loans, this may be impossible. Alternatively, they could raise new equity. However, since profits accumulate only over time and recapitalization can only be pursued with some lead time, this instrument has to be used more carefully than ABRRs. This is most likely the reason why Goodhart (2009: 95-97) advocates raising them only on the recorded asset and loan growth of a bank. This will be less effective in disrupting a bubble but still limit exposure, reduce the effects of leverage targeting and build up buffers. Alternatively, if the authorities announce the measure early enough, FIs would have time to limit exposure and raise capital. Likewise, a ladder of sanctions that would require FIs falling short of the requirement to face certain restrictions until they fulfill it might make the proposal workable. This could make the instrument effective while giving flexibility to the special circumstance of some actors (Brunnermeier et al. 2009: 36).

\section{Conclusion}

The toolkit for preventing asset-price bubbles is comparatively small. This lack became apparent with the recent crisis. However, the literature offers a range of proposals for possible instruments. Most of them suffer from a lack of experience about their working and about possible adverse side-effects, as for example experienced with the Basel II capital requirements. Consequently, at least a serious theoretical discussion should precede the implementation of any new policy instrument. This paper compares the effect of two different proposals - asset-based reserve requirements and asset-based capital requirements - regarding their effectiveness in preventing asset price bubbles.

It has been shown that both should have a dampening effect on asset price inflation by reducing the amount of credit money flowing into the asset and by reducing the incentive for FIs to invest in inflating asset classes. For loans, the instrument should work through a price effect which should dampen demand. With ABRRs, the magnitude of the effect should be the costs of holding the reserves. With ABCRs, the effect cannot precisely be determined. Basically, if equity was easy to raise it should be the shadow costs of equity minus the costs of debt. However, the effect is hard to measure, may vary over time and among countries and its impact on the price of credit is not well understood yet (Basel Committee on Banking Supervision 20I0: 3 ). The effect could be nil but could also become a quantitative supply restraint. Therefore, the potential moderating effect on the upswing should rather be seen 
as a positive side effect and ABCRs do not seem to be the best suited instrument for the purpose of targeting asset price bubbles until their effects are fully understood.

The effect on investment decisions by FIs was demonstrated with the help of the ROE equation. ABRRs increase the costs of holding an asset and so lower the ROE. The effect of ABCRs works through raising the amount of employed equity which mechanically reduces the ROE. However, the more interesting effect of the latter is that it enables regulators to annul leverage spirals. There is a possibility that ABRRs also affect excessive leveraging indirectly via reducing the possibility of refinancing in the repo market. However, this needs further examination before a firm statement about the effect can be made.

To sum up, ABRRs seem to have a more predictable effect and would more likely only work through the price/ROE-channel. For ABCRs, the effect is less predictable and may vary or even become a supply side constraint. Therefore, reserve requirements seem more suitable than capital requirements for targeted action on specific markets.

Because of the space limitations, many issues that may be important had to be omitted within this paper. The merits of the released reserves and capital buffers during a bust would be an interesting matter to look at. For the practical implementation of the instruments there are a lot of further topics that need to be discussed in depth. Problems ignored in this theoretical outline, but highly relevant in practice are the disintermediation and boundary problem. Also the advantages and disadvantages of implementing the proposals as rulebased systems or discretionary instruments would be fruitful topics for further discussion. Further, contrasting the proposed instruments with the already existing or currently phased in regulation as for example BASEL III could lead to interesting insights.

\section{References}

Admati, A.R., DeMarzo, P.M., Hellwig, M.F., Pfleiderer, P. (20I0): Fallacies, irrelevant facts, and myths in the discussion of capital regulation: Why bank equity is not expensive, Research Paper 2065, Stanford University, Graduate School of Business.

Adrian, T., Shin, H.S (2008a): Liquidity and financial contagion, in: Financial Stability Review, II(II), I-7.

Adrian, T., Shin, H.S (2008b): Liquidity and financial cycles, BIS Working Papers 256, Bank for International Settlements.

Bailey, R.E. (2005): The Economics of Financial Markets, Cambridge: Cambridge University Press.

Bank for International Settlements (2009): The role of valuation and leverage in procyclicality, Geneva: Bank for International Settlements.

Barwell, R., Burrows, O. (20II): Growing fragilities? Balance sheets in the Great Moderation, Bank of England Financial Stability Paper, (Io).

Basel Committee on Banking Supervision (1999): Capital requirements and bank behaviour: The impact of the Basel accord, BIS Working Papers I, Bank for International Settlements, April.

Basel Committee on Banking Supervision (20IO): Countercyclical capital buffer proposal. Consultative Document, Bank for International Settlements, July. 
Berger, A.N., Udell, G.F. (2003): The institutional memory hypothesis and the procyclicality of bank lending behaviour, BIS Working Papers 125, Bank for International Settlements, January.

Brunnermeier, M., Crocket, A., Goodhart, C., Persaud, A.D., Shin, H.S. (2009): The fundamental principles of financial regulation, Geneva Reports on the World Economy II, International Center for Monetary and Banking Studies.

Davidson, P. (2002): Financial Markets, Money, and the Real World, Cheltenham: Edward Elgar.

Davis, J. (1997): J.M. Keynes on history and convention, in: Riach P.A, Harcourt G.C. (eds.), A ,Second Edition of the General Theory, volume 2, London: Routledge, I49-163.

Demirguc-Kunt, A., Detragiache, E., Merrouche, Q. (20I0): Bank capital: Lessons from the financial crisis, IMF Working Papers Io/286, International Monetary Fund, December.

Dudley, W.C. (20I0): Asset bubbles and the implications for central bank policy, Speech at the Economic Club of New York, April 20IO, URL: http:/www.er.ethz.ch/fco/Asset_ bubbles.

European Central Bank (20I0): ECB Annual Report 20IO, Frankfurt am Main, URL: http:// www.ecb.europa.eu/pub/pdf/annrep/ar2oIoen.pdf

European Central Bank (20IIa): ECB Statistical Data Warehouse, URL: http://sdw.ecb.europa. eu/quickview.do?SERIES_KEY=I24.MIR.M.U2.B.A22.J.R.A.2250.EUR.O.

European Central Bank (20IIb): ECB: Key interest rates. 20II, URL: http://www.ecb.de/stats/ monetary/rates/html/index.en.html.

Erturk, K.A. (2006): Speculation, liquidity preference and monetary circulation, in: Arestis, P., Sawyer, M.C. (eds.), A Handbook of Alternative Monetary Economics, Cheltenham: Edward Elgar, 454-470.

Goodhart, C.A.E. (2008): Central banks' function to maintain financial stability: An uncompleted task, June, URL: http://voxeu.org/index.php?q=node/I263.

Goodhart, C.A.E. (2009): The Regulatory Response to the Financial Crisis, Cheltenham: Edward Elgar.

Goodhart, C.A.E., Hofmann, B. (2006): House Prices and the Macroeconomy: Implications for Banking and Price Stability, Oxford: Oxford University Press.

Gorton, G. (2009): Slapped in the face by the invisible hand: Banking and the panic of 2007, Prepared for the Federal Reserve Bank of Atlanta's 2009 Financial Markets Conference: Financial Innovation and Crisis, May II-I3, URL: http://www.frbatlanta.org/news/ Conferen/ogfmc/gorton.pdf.

Hanson, S.G., Kashyap, A.K., Stein, J.C. (20II): A macroprudential approach to financial regulation, in: Journal of Economic Perspectives, 25(I), 3-28.

Holz, M. (2007): Asset-based reserve requirements: A new monetary policy instrument for targeting diverging real estate prices in the euro area, in: Intervention. European Journal of Economics and Economic Policies, 4(2), 33I-35I.

Hördahl, P., King, M.R. (2008): Developments in repo markets during the financial turmoil, BIS Quarterly Review, December.

International Monetary Fund (2OII): Macroprudential policy: An organizing framework, IMF Policy Paper, International Monetary Fund. 
Kaldor, N. (1939): Speculation and economic stability, in: The Review of Economic Studies, 7(I), I- 27.

Karagiannis, S., Panagopoulus, Y., Spiliotis, A. (20II): The Basel II influence on the money supply process, in: Rochon, L., Gnos, C. (eds.), Credit, Money and Macroeconomic Policy: A Post-Keynesian Approach, Cheltenham: Edward Elgar.

Kowalik, M. (20II): Countercyclical capital regulation: Should bank regulators use rules or discretion?, in: Federal Reserve Bank of Kansas City Economic Review, Second Quarter 2OII, 63-84.

Kregel, J. (2008): Using Minsky's cushions of safety to analyze the crisis in the U.S. subprime mortgage market, in: International Journal of Political Economy, 37(I), 3-23.

Minsky, H.P. (1975): John Maynard Keynes, Columbia: Columbia University Press. Minsky, H.P. (1982): Can »it« Happen Again? Essays on Instability and Finance, Armonk, N.Y: M.E. Sharpe.

Minsky, H.P. (2008a): The financial-instability hypothesis: Capitalist processes and the behavior of the economy, in: Kindleberger, C.P., Laffargue, J. (eds.), Financial Crises: Theory, History \& Policy, Cambridge: Cambridge University Press, 13-47.

Minsky, H.P. (2008b ): Stabilizing an Unstable Economy, New York: The McGraw Hill Companies. Modigliani, F., Miller, M.H. (1958): The cost of capital, corporation finance and the theory of investment, in: The American Economic Review, 48(3), 26I-297.

Palley, T.I. (2000): Stabilizing finance: The case for asset-based reserve requirements, report issued by the Financial Markets Center, Philomont, VA, August 2000.

Palley, T.I. (2003): Asset price bubbles and the case for asset-based reserve requirements, in: Challenge, 46(3), 53-72.

Palley, T.I. (2004): Asset-based reserve requirements: Reasserting domestic monetary control in an era of financial innovation and instability, in: Review of Political Economy, I6(I), 43-58.

Palley, T.I. (2007): Asset-based reserve requirements: A response, in: Review of Political Economy, I9 (4), 575- 578 .

Palley, T.I. (20I0): Asset price bubbles and monetary policy: Why central banks have been wrong and what should be done, in: Intervention. European Journal of Economics and Economic Policies, 7(I), 9I-107.

Persaud, A. (2009): The rise and apparent fall of macro-prudential regulation, June, URL: http:// www.voxeu.org/index.php?q=node/3694.

Stiglitz, J.E., Weiss A. (198I): Credit rationing in markets with imperfect information, in: American Economic Review, 7I(3), 393-4IO.

Van den Heuvel, S.J. (2002): Does bank capital matter for monetary transmission?, in: Federal Reserve Bank of New York Economic Policy Review, Vol. 8, No. I, 259-265.

Wray, L.R., Tymoigne, E. (2008): Macroeconomics meets Hyman P. Minsky: The financial theory of investment, Levy Economics Institute, Working Paper 543. 